\title{
In Vitro Antibody-Enzyme Conjugates with Specific Bactericidal Activity
}

\author{
Daniet M. Knowles, II, Timothy J. Sullivan, III, Charles W. Parker, and \\ Ralph C. WILLIaMs, JR. \\ From the Department of Medicine, Bernalillo County Medical Center, \\ University of New Mexico School of Medicine, Albuquerque, New Mexico \\ 87131, and the Department of Medicine, Washington University School of \\ Medicine, Barnes and Wohl Hospitals, St. Louis, Missouri 63110
}

\begin{abstract}
- A в S T R A C T IgG with antibacterial antibody opsonic activity was isolated from rabbit antisera produced by intravenous hyperimmunization with several test strains of pneumococci, Group A $\beta$-hemolytic streptococci, Staphylococcus aureus, Proteus mirabilis, Pseudomonas aeruginosa, and Escherichia coli. Antibody-enzyme conjugates were prepared, using diethylmalonimidate to couple glucose oxidase to IgG antibacterial antibody preparations. Opsonic human IgG obtained from serum of patients with subacute bacterial endocarditis was also conjugated to glucose oxidase. Antibody-enzyme conjugates retained combining specificity for test bacteria as demonstrated by indirect immunofluorescence. In vitro test for bactericidal activity of antibody-enzyme conjugates utilized potassium iodide, lactoperoxidase, and glucose as cofactors. Under these conditions glucose oxidase conjugated to antibody generates hydrogen peroxide, and lactoperoxidase enzyme catalyzes the reduction of hydrogen peroxide with simultaneous oxidation of $\mathrm{I}^{-}$and halogenation and killing of test bacteria. Potent in vitro bactericidal activity of this system was repeatedly demonstrated for antibody-enzyme conjugates against pneumococci, streptococci, $S$. aureus, $P$. mirabilis, and $E$. coli. However, no bactericidal effect was demonstrable with antibody-enzyme conjugates and two test strains of $P$. aeruginosa. Bactericidal activity of antibody-enzyme conjugates appeared to parallel original opsonic potency of unconjugated IgG preparations. Antibody-enzyme conjugates at concentrations as low as $0.01 \mathrm{mg} / \mathrm{ml}$ were capable of intense bactericidal activity producing substantial drops in surviving bacterial counts within $30-60 \mathrm{~min}$ after initiation of assay. These in vitro bactericidal systems indicate that the concept of antibacterial antibody-enzyme conjugates may
\end{abstract}

Received for publication 4 December 1972 and in revised form 22 January 1973. possibly be adaptable as a mechanism for treatment of patients with leukocyte dysfunction or fulminant bacteremia.

\section{INTRODUCTION}

Certain peroxidases have been shown to exhibit potent antimicrobial activity when combined with hydrogen peroxide and an oxidizable cofactor such as iodide, bromide, chloride, or thiocyanate ions (1-4). The neutrophil peroxidase, myeloperoxidase (MPO), ${ }^{1}$ has been shown to possess bactericidal $(1-3,5,6)$, fungicidal $(7,8)$, virucidal $(9)$, and spermicidal $(10)$ activity.

The purpose of this study was to construct a specific in vitro bactericidal system utilizing a peroxide-generating enzyme chemically linked to antibacterial antibody. In this way, it was hoped that antibacterial antibody specificity could be directly coupled to the potent bactericidal system involved with hydrogen peroxide generation. Isolated rabbit IgG antibodies produced against the different organisms to be tested were conjugated to glucose oxidase, an enzyme capable of generating hydrogen peroxide in the presence of glucose. Antibodyenzyme conjugate and test organism were incubated and washed and an MPO substitute (lactoperoxidase or horseradish peroxidase), potassium iodide, and glucose were added. This mixture was incubated and sampled for bacterial viability according to a modification (11) of the in vitro phagocytosis test of Maaløe (12). Two bacterial strains recovered from a patient with subacute bacterial endocarditis ( $\mathrm{SBE}$ ) were tested in the same

${ }^{1}$ Abbreviations used in this paper: BBS, balanced salt solution; DEM, diethylmalonimidate; HPO, horseradish peroxidase; LPO, lactoperoxidase; MPO, myeloperoxidase; PBS, phosphate-buffered saline; SBE, subacute bacterial endocarditis. 
manner with an antibody-enzyme conjugate prepared from the patients' own immune IgG fraction.

The results reported here indicate that a bacterial species may be specifically killed in vitro by a system postulated to operate in the normal leukocyte in vivo. This system may have important clinical implications for those patients with a qualitative or quantitative leukocyte defect. It is conceivable that the concept of specific antibody-enzyme conjugates may eventually provide a practical approach applicable to a number of therapeutically difficult infections of man.

\section{METHODS}

Bacteria. Six bacterial species were used as test organisms in this study: $P$. mirabilis, $P$. aeruginosa, $E$. coli, $D$. pneumoniae, Group A streptococcus and $S$. aureus. The strains of $P$. mirabilis and $P$. aeruginosa were isolated from three osteomyelitis patients previously studied: GIL (proteus), LAH and STA (pseudomonas) (13). The strain of E. coli (STO) was isolated from a patient with septicemia. The strain of $D$. pneumoniae (QUI) was obtained from R. C. Williams, J. H. Dossett, and P. G. Quie, and the Cowan I strain of $S$. aureus was that previously studied in this laboratory (13). The M-33 strain of $\beta$-hemolytic streptococcus Group A (MOR) was obtained from Dr. E. T. Mortimer. Two additional strains of $S$. aureus (ELL-W and ELL-Y) were simultaneously isolated from blood cultures of a heroin addict with active SBE. The selection of these six bacterial species, $P$. mirabilis, $P$. aeruginosa, $E$. coli, $D$. pneumoniae, Group A $\beta$-hemolytic streptococcus, and $S$. aureus was based on the following considerations: (a) By virtue of their virulence and/or drug resistance these organisms often cause life-threatening infections in debilitated patients. It therefore appeared important to demonstrate effective bactericidal activity by antibody-enzyme conjugates against representative strains of these organisms. (b) The relationship of bacterial hydrogen peroxide and catalase production to the susceptibility of these organisms to intracellular killing by leukocytes from patients with chronic granulomatous disease has been shown to be significant (14). It was considered desirable to test both catalase- and noncatalase-producing organisms to see if the catalase producers, $S$. aureus, $P$. mirabilis, $P$. aeruginosa, and $E$. coli, fared better than the noncatalase producers, pneumococcus and Group A streptococcus, when challenged by the antibody-enzyme conjugate test system. (c) The test organisms had previously been extensively studied in this laboratory and were known to grow well $(13,15)$ in the modified phagocytosis test system $(11,12)$, which employs colony counting to enumerate surviving bacteria. (d) The corresponding antibodies prepared in rabbits had previously been shown not to be intrinsically bactericidal in phagocytosis test systems while demonstrating effective bacterial agglutinating and opsonic activity $(13,15)$.

Bacteria to be studied were maintained on appropriate agar slants. $24 \mathrm{~h}$ before testing, sterile 25 -by-150 screw top tubes with either Penassay broth (Difco Laboratories, Detroit, Mich.) for staphylococcus, Group A streptococcus, proteus, pseudomonas, and $E$. coli or tryptose phosphate broth (Difco) for pneumococcus were inoculated from these agar slants and incubated at $37^{\circ} \mathrm{C}$. At testing time these same culture tubes were centrifuged, the supernatant discarded, and the pellet washed once with $10 \mathrm{ml}$ of sterile

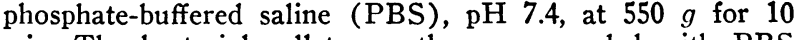
min. The bacterial pellet was then resuspended with PBS to an optical density of $0.60-0.70$ at $620 \mathrm{~nm}$ in a Coleman Junior II Spectrophotometer (Coleman Instruments Div., Perkin-Elmer Corp., Maywood, Ill.). Bacterial suspensions were diluted with $0.1 \%$ gel Hanks's balanced salt solution (BSS), prepared without glucose according to the National Institutes of Health modification (i.e., without $\mathrm{Mg}$ $\mathrm{Cl}_{2}$ ). The dilution was appropriate for each organism such that baseline colony counts were in a suitable range, i.e., 200-500 colonies per plate. All tests for bactericidal activity were performed in duplicate and variability of duplicate tests was never more than $5 \%$. Reproducibility of individual test data was excellent when the same test was performed on different days. Representative data shown in figures were obtained in individual experiments where duplicate plates were used and mean numbers of surviving bacteria shown.

Antisera. Rabbits were injected with $1 \mathrm{ml}$ of $2 \times 10^{8}$ to $4 \times 10^{8}$ heat-killed bacterial suspension intravenously three times weekly and then bled after 3-8 wk of immunization. IgG was obtained from rabbit and human sera using DEAE columns and a $0.015 \mathrm{M}$ phosphate buffer, $\mathrm{pH} 6.4$ (13). Immunoelectrophoresis against antiwhole rabbit serum and various antirabbit Ig antisera confirmed that isolated rabbit IgG immunoglobulins contained only IgG.

Conjugation. The rabbit IgG fractions were dialyzed overnight against $1,000 \mathrm{ml}$ of distilled water at $4^{\circ} \mathrm{C}, 1 \mathrm{y}-$ ophilized, and stored at $0^{\circ} \mathrm{C}$ until needed for conjugation. The chemical conjugation procedure of enzyme to antibody was adopted as a modification of the method of Dutton, Adams, and Singer (16) and was performed in a glass tube placed on top of a magnetic stirring plate and clamped to a ring stand. For each $1 \mathrm{ml}$ of lyophilized IgG containing antibacterial antibody added to the test tube, $2 \mathrm{mg}$ of glucose oxidase, $20 \mu \mathrm{l}$ of a $0.2 \mathrm{M}$ sodium borate solution

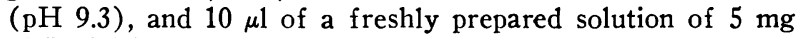
of DEM in $0.3 \mathrm{ml}$ of $0.2 \mathrm{M}$ sodium borate $(\mathrm{pH} 9.3)$ were added. This mixture was stirred continuously for $30 \mathrm{~min}$ at room temperature with a magnetic stirring rod. $10 \mu 1$ of a newly prepared solution of $5 \mathrm{mg}$ of $\mathrm{DEM}$ in $0.3 \mathrm{ml}$ of $0.2 \mathrm{M}$ sodium borate ( $\mathrm{pH}$ 9.3) was added twice more followed by 30 -min periods of continuous mixing at room temperature. $30 \mu \mathrm{l}$ of a $1 \mathrm{M} \mathrm{NaH} \mathrm{PO}_{4}$ solution was added, lowering the mixture $\mathrm{pH}$ from 9.3 to 6.5 , and the mixture was immediately placed in an ice bath. $58 \mu$ l of a $100 \%$ saturated $\left(\mathrm{NH}_{4}\right)_{2} \mathrm{SO}_{4}$ solution (stored at $4^{\circ} \mathrm{C}$ ) was added and the mixture allowed to remain in ice for $30 \mathrm{~min}$. The precipitated conjugate of antibody and glucose oxidase was then centrifuged at $4^{\circ} \mathrm{C}$ in a Sorvall RC2-B refrigerated centrifuge (Ivan Sorvall, Inc., Newtown, Conn.) at $755 \mathrm{~g}$ for $30 \mathrm{~min}$. The supernatant was discarded and the precipitate washed three times with $1 \mathrm{ml}$ aliquots of a $42 \%$ saturated $\left(\mathrm{NH}_{4}\right)_{2} \mathrm{SO}_{4}$ solution. Previous experiments using these methods have shown that unconjugated and self-coupled glucose oxidase is soluble in $42 \%\left(\mathrm{NH}_{4}\right)_{2} \mathrm{SO}_{4}$. The conjugate was dissolved in PBS ( $\mathrm{pH} 7.4)$ and dialyzed against $500 \mathrm{ml}$ of distilled water for $60 \mathrm{~min}$. The solution was then dialyzed at $4^{\circ} \mathrm{C}$ against $500 \mathrm{ml}$ of PBS $(\mathrm{pH} \mathrm{7.4)}$ for $24 \mathrm{~h}$ with three to five changes.

The antibody-glucose oxidase conjugate was further diluted with $\mathrm{PBS}(\mathrm{pH}$ 7.4) to yield final concentrations close to $1 \mathrm{mg} / \mathrm{ml}$. The glucose oxidase-antibody conjugate concentrations and their specificities are shown in Table I. Conjugates were assayed for glucose oxidase activity by the method of Keston and Brandt (17) and contained an average of 1 active glucose oxidase molecule per 10 anti- 
TABLE I

Summary of Specificities and Protein Concentrations of Antibody-Enzyme Conjugates

\begin{tabular}{|c|c|c|c|c|}
\hline $\begin{array}{l}\text { Antibody-enzyme } \\
\text { conjugate }\end{array}$ & $\begin{array}{l}\text { Source of } \\
\text { antibody }\end{array}$ & Specificity & $\begin{array}{c}\text { Final protein } \\
\text { concentration } \\
\text { before dilution }\end{array}$ & $\begin{array}{l}\text { Opsonic titer* } \\
\text { of isolated IgG } \\
\text { preparation before } \\
\text { conjugation }\end{array}$ \\
\hline & & & $m g / m l$ & \\
\hline Anti-QUI & Rabbit & Pneumococcus, QUI strain & 1.27 & $1: 200$ \\
\hline Anti-Cowan I & Rabbit & S. aureus, Cowan I strain & 1.40 & $1: 150$ \\
\hline Anti-MOR & Rabbit & $\begin{array}{l}\text { Group A } \beta \text {-hemolytic streptococcus M-33 } \\
\text { strain MOR }\end{array}$ & 1.10 & $1: 200$ \\
\hline Anti-GIL & Rabbit & P. mirabilis, GIL strain & 1.46 & $1: 20$ \\
\hline Anti-LAH & Rabbit & $P$. aeruginosa, LAH strain & 1.06 & $1: 10$ \\
\hline Anti-STA & Rabbit & $P$. aeruginosa, STA strain & 1.06 & $1: 10$ \\
\hline Anti-STO & Rabbit & E. coli, STO strain & 1.03 & $1: 100$ \\
\hline Anti-ELL & Human & S. aureus, yellow and white strains & 1.13 & $1: 10$ \\
\hline
\end{tabular}

* Opsonic titer refers to last dilution of isolated IgG preparations starting at $1.0 \mathrm{mg} / \mathrm{ml}$ which was capable of producing a one-log drop in surviving organisms during in vitro phagocytosis testing using bacteria, normal human polymorphonuclear cells, and dilutions of IgG containing antibody to test bacteria.

body molecules. The yield of IgG-enzyme conjugate from lyophilized IgG was $75-95 \%$ of starting material. Because of the absorbency of glucose oxidase at or near $400 \mathrm{~nm}$ where antibody solutions are largely transparent, it was possible to estimate the amount of total enzyme protein in the conjugates. On this basis, typical conjugates contained about $25 \%$ (by weight) of glucose oxidase, suggesting a loss of as much as $60 \%$ of the overall enzyme activity during conjugation.

Clear evidence that antibacterial IgG-enzyme conjugate preparations repeatedly utilized in this study actually retained antibody activity against the various bacteria was sought, using tests of agglutinating, complement fixing, precipitating activity, and direct combination with bacteria by indirect immunofluorescence. In most instances very little or weak direct agglutinating activity was recorded in these preparations of IgG and this type of reactivity was either lost or diminished in the DEM-treated antibody-enzyme conjugate (Table II). In like manner, complement fixing as well as precipitating activity of these same IgG preparations was lost or markedly reduced after conjugation. However, the IgG-enzyme conjugates could be clearly shown to combine with test bacterial species by indirect immunofluorescence. Immunofluorescence controls using bacteria and goat antirabbit IgG without conjugate or antibacterial IgG were negative. These data are summarized in Table II.

Test system. A modification (11) of the in vitro phagocytosis test of Maalфe (12) was employed which substituted antibody-enzyme conjugates and essential activating cofactors for leukocytes. Falcon no. 2003 disposable plastic tubes (Falcon Plastics, Div. of B-D Laboratories, Inc., Los Angeles, Calif.) were utilized for reagent mixing. The reagents employed were lactoperoxidase (LPO) or horseradish peroxidase (HPO) from Sigma Chemical Co., St. Louis, Mo., or HPO from Nutritional Biochemicals Corporation, Cleveland, Ohio, $(10 \mathrm{mg} / \mathrm{ml})$, potassium iodide solution $(1.4 \times$ $\left.10^{-4} \mathrm{M}\right)$, glucose $(14 \mathrm{mg} / \mathrm{ml})$, and conjugated or unconjugated IgG (Table I). The bacteria, conjugated antibody, and

TABLE II

Antibody Activity of Rabbit Antibacterial IgG before and after Conjugation to Glucose Oxidase

\begin{tabular}{|c|c|c|c|c|c|c|c|c|}
\hline \multirow[b]{2}{*}{ Organism tested } & \multicolumn{2}{|c|}{ Agglutination } & \multicolumn{2}{|c|}{ Complement fix. } & \multicolumn{2}{|c|}{ Precipitation } & \multicolumn{2}{|c|}{$\begin{array}{l}\text { Antibacterial binding } \\
\text { by immunofluorescence }\end{array}$} \\
\hline & Unconj. & Conj. & Unconj. & Conj. & Unconj. & Conj. & Unconj. & Conj. \\
\hline Pneumococcus QUI & $0^{*}$ & 0 & $1: 16$ & 0 & 0 & 0 & $\begin{array}{l}4+ \\
1: 200\end{array}$ & $\begin{array}{l}4+ \\
1: 100\end{array}$ \\
\hline S. aureus Cowan I & $1: 4$ & 0 & $1: 8$ & 0 & 0 & 0 & $\begin{array}{l}4+ \\
1: 400\end{array}$ & $\begin{array}{l}4+ \\
1: 100\end{array}$ \\
\hline$P$. aeruginosa STA & $1: 4$ & $\mathbf{0}$ & $1: 4$ & 0 & + & 0 & $\begin{array}{l}4+ \\
1: 100\end{array}$ & $\begin{array}{l}4+ \\
1: 50\end{array}$ \\
\hline P. mirabilis GIL & $1: 31$ & $1: 16$ & $1: 32$ & $1: 2$ & + & $\pm \ddagger$ & $\begin{array}{l}4+ \\
1: 50\end{array}$ & $\begin{array}{l}4+ \\
1: 25\end{array}$ \\
\hline
\end{tabular}

* Reciprocal titer.

$\ddagger \pm$ denotes absent direct precipitation, but distinct inhibition of precipitation in agar gel. 
(A)<smiles>COC(=N)CC(N)=O</smiles><smiles>[R]N[I-][3H]</smiles><smiles>[R7]NC([NH3+])CC(N)(N)N[R]</smiles>

$R^{\prime}=$ glucose oxidose

$R^{\prime \prime}=$ antibacterial antibody
(8)

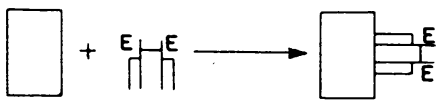

(c)

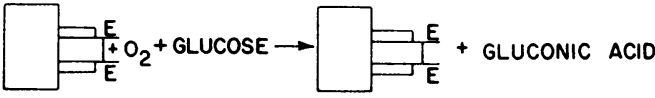

(D)

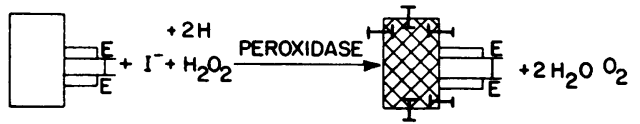

FIGURE 1 (A) Diethylmalonimidate (DEM) is used to conjugate the $\mathrm{H}_{2} \mathrm{O}_{2}$-generating enzyme, glucose oxidase, to the antibacterial antibody. (B) During incubation the antibacterial antibody-enzyme conjugate fixes to the bacteria. $\mathrm{E}$ denotes the presumed position of the glucose oxidase enzyme. (C) In the presence of glucose, hydrogen peroxide is generated. (D) The peroxidase enzyme catalyzes the reduction of $\mathrm{H}_{2} \mathrm{O}_{2}$ and the simultaneous oxidation of $\mathrm{I}^{-}$, halogenating the bacterium and killing it.

unconjugated antibody were diluted with $0.1 \%$ gel Hanks's BSS prepared according to the NIH modification (i.e., without $\mathrm{MgCl}_{2}$ ) and without glucose or $\mathrm{NaHCO}_{3}$.

$0.1 \mathrm{ml}$ of the conjugated or unconjugated antibody diluted with $0.1 \%$ gel Hanks's BSS were added, followed by $0.1 \mathrm{ml}$ of the appropriately diluted bacterial suspension, and the volume raised to $1.0 \mathrm{ml}$ with gel Hanks's BSS. These mixtures were incubated at $37^{\circ} \mathrm{C}$ for $60 \mathrm{~min}$ with constant tumbling at $10 \mathrm{rpm}$ on a Fisher Roto-Rack (Fisher Scientific Company, Pittsburgh, $\mathrm{Pa}$.). The tubes were then centrifuged at $550 \mathrm{~g}$ for $10 \mathrm{~min}$, the supernatant discarded, and the pellets washed with $1 \mathrm{ml}$ aliquots of gel Hanks's BSS at $550 \mathrm{~g}$ for $10 \mathrm{~min}$. The remaining reagents, LPO or HPO, a peroxidase source, potassium iodide as a halide source, and glucose, the substrate for glucose-oxidase, were added $(0.1 \mathrm{ml}$ of each) and the total volume of each tube raised to $1.0 \mathrm{ml}$ with $0.1 \%$ gel Hanks's BSS. Final concentrations of LPO or HPO were varied in individual experiments from 1 to $1000 \mu \mathrm{g}$. Effective killing was of ten recorded using as little as $1-10 \mu \mathrm{g}$ of LPO. Controls also included glucose oxidase unconjugated to antibacterial antibody. The entire bactericidal effector system is diagrammed in Fig. 1. The tubes were rotated end-over-end by hand to insure adequate mixing and were immediately sampled. They were then returned to the incubator and tumbled in the RotoRack continuously while being sampled at 30,60, and 120 min. Sampling was performed with a $0.001 \mathrm{ml}$ calibrated platinum loop diluting in $1.0 \mathrm{ml}$ of distilled water. $0.001 \mathrm{ml}$ of this 1:1000 mixture was then placed on standard sterile disposable plastic 100 -by- $15-\mathrm{mm}$ petri dishes and appropriate agar poured after each sampling. The plates were incubated at $37^{\circ} \mathrm{C}$ for $24 \mathrm{~h}$ and the colonies counted on a Quebec darkfield colony counter.

\section{RESULTS}

\section{Studies with rabbit antibody}

Diplococcus pneumoniae. The success of the bactericidal system under study appeared to be dependent upon the presence of effective antibacterial (opsonic) activity in the rabbit antisera as assayed in the in vitro phagocytosis test $(11,12)$. Excellent opsonic activity (two$\log$ reduction in colony counts) was noted for the isolated IgG antibody against test pneumococcus strain

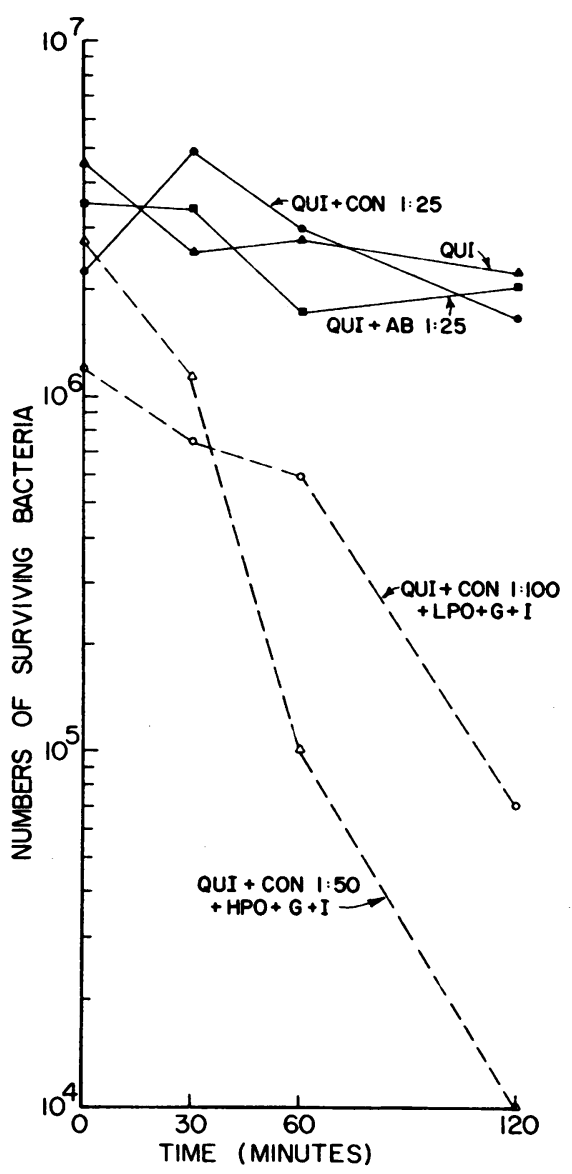

FIgURe 2 Bacterial activity demonstrable when QUI strain of pneumococcus was incubated with anti-QUI conjugate diluted $1: 50$ or $1: 100$, LPO or HPO, potassium iodide, and glucose. Representative controls using high concentrations of antibody, conjugated and unconjugated, do not exhibit intrinsic bactericidal activity, thus QUI + CON $1: 25$ represents test organism QUI plus antibody-enzyme conjugate in a 1:25 dilution; also QUI + AB 1:25 indicates unconjugated antibody diluted $1: 25$ plus test bacteria. QUI represents colony counts of bacteria alone. No killing occurred with these controls or with LPO, iodide, or glucose, alone or in combination. In addition, unconjugated glucose oxidase not linked to IgG antibody did not produce killing. Bactericidal activity was observed only when a complete system of organism, antibody-enzyme conjugate, LPO or HPO, glucose (G), and iodide (I) was present.

1446 D. M. Knowles, T. J. Sullivan, C. W. Parker, and R. C. Williams 
TABLE III

Representative Experimental Results and Colony Counts Obtained for All Controls as well as the Complete Test System Utilizing QUI Pneumococcus and Rabbit Antibody-Glucose Oxidase Enzyme Conjugate

\begin{tabular}{cccccccccc}
\hline $\begin{array}{c}\text { Enzyme-IgG } \\
\text { conjugate* }\end{array}$ & $\begin{array}{c}\text { Antibody* } \\
\text { alone }\end{array}$ & LPO* & HPO* & KI* & Glucose & 0 mint & 30 minf & 60 minf & 120 minf \\
\hline- & - & - & - & - & - & 450 & 255 & 280 & 225 \\
$1: 25$ & - & - & - & - & - & 225 & 490 & 300 & 170 \\
$1: 100$ & - & - & - & - & - & 240 & 200 & 230 & 220 \\
- & $1: 25$ & - & - & - & - & 350 & 340 & 175 & 210 \\
- & $1: 100$ & - & - & - & - & 175 & 180 & 200 & 145 \\
$1: 25$ & - & - & - & - & + & 350 & 330 & 355 & 140 \\
$1: 100$ & - & + & - & - & + & 375 & 200 & 380 & 510 \\
$1: 100$ & - & + & - & + & - & 180 & 175 & 230 & 170 \\
- & - & + & - & + & + & 300 & 255 & 580 & 380 \\
- & $1: 100$ & + & - & + & + & 260 & 200 & 250 & 240 \\
$1: 100$ & - & + & - & + & + & 120 & 75 & 60 & 7 \\
$1: 25$ & - & - & + & + & + & 185 & 80 & 5 & 0 \\
$1: 50$ & - & - & + & + & + & 275 & 115 & 10 & 1 \\
$1: 100$ & - & - & + & + & + & 120 & 80 & 0 & 0 \\
\hline
\end{tabular}

* The left-hand columns show the reagent combinations and the dilutions employed.

$\ddagger$ The right-hand four columns show number of surviving bacteria $\times 4.5 \times 10^{7}$, at $0,30,60$, and 120 min of sampling in bactericidal assay. Bacterial colony counts were performed in duplicate and mean of colony counts is shown here.

QUI. It was therefore not surprising that the pneumococcus was one of the organisms most effectively killed by the antibacterial antibody conjugated to glucose oxidase. Combination of glucose oxidase-antibody conjugate, LPO or HPO, potasium iodide, and glucose was markedly bactericidal for the test bacteria. The conjugate appeared to be rapidly bactericidal in dilutions of $1: 25,1: 50$, or $1: 100$ and whether combined with either LPO or HPO as a peroxidase source. Representative results are shown in Fig. 2 and Table III. For the QUI pneumococcus $0.1 \mathrm{ml}$ of a $1: 100$ dilution of conjugated IgG delivered only $1.27 \times 10^{-8} \mathrm{mg}$ of total antibody-enzyme conjugate. It must be emphasized that antibacterial antibodies used in these experiments were constituted from IgG obtained from hyperimmunized rabbits and that specific antibodies were not further purified by any attempts at elution from immunoabsorbents. Thus specific antibacterial antibody probably constituted a minority of the IgG molecules in such preparations.

The experiments employing HPO were performed a full 3 wk after the studies with LPO and without a decrease in bactericidal activity. These latter experiments indicated the apparent stability of the antibodyenzyme conjugate.

An incomplete conjugate system, individual reagents, or incomplete combinations failed significantly to depress colony counts. This was true of the conjugated or unconjugated antibody alone in as small a dilution as $1: 25$. Thus the antibody, conjugated or unconjugated to enzyme, was not intrinsically bactericidal and could not be implicated to be responsible for bactericidal activity. Each and every component of the system was necessary and killing did not occur if any single component was absent (Table III). In addition, use of glucose oxidase unconjugated to antibody in concentrations from 0.001 to $1.0 \mathrm{mg} / \mathrm{ml}$ did not produce significant killing.

Perhaps the single most important control was the combination of antibody-enzyme conjugate and glucose without potassium iodide or a peroxidase. Glucose oxidase in high concentrations in the presence of glucose will generate hydrogen peroxide and gluconic acid. Gluconic acid will lower the $\mathrm{pH}$ sufficiently to kill the bacteria by a nonspecific or acidifying effect. The problem of local $\mathrm{pH}$ change in the test bacterial microenvironment was circumvented in our study by incubating only the organism and its conjugated antibody followed by careful washing to remove all excess IgG not attached to the bacteria. Since the control combination of glucose oxidase-antibody conjugate and glucose and glucose oxidase not conjugated to antibody did not exhibit bactericidal activity, the bactericidal effect observed with the complete system could be interpreted to be a specific consequence of the conjugated antibody system.

Staphylococcus aureus. A Cowan I strain of $S$. aureus was studied. This strain is an excellent producer of protein A (18) and is a highly virulent strain of $S$. aureus. Furthermore, this organism is a catalase producer whereas pneumococcus is not (14). Isolated IgG from immune rabbit antisera to Cowan I demonstrated excellent opsonic activity (two-log reduction in colony 
counts) using the in vitro phagocytosis test system and normal human leukocytes $(11,12)$. No intrinsic killing by IgG preparations of antibacterial antibody alone without leukocytes was recorded.

The first peroxidase employed against Cowan I was LPO obtained from Sigma Chemical Company, the same peroxidase successfully used against the test strain of pneumococcus. A 1:100 dilution of the antibody-enzyme conjugate and with the addition of LPO, potassium iodide, and glucose, demonstrated bactericidal activity. The killing effect was not as great as with the test strain of pneumococcus but was definite and reproducible (Fig. 3). Again, a complete system, antibody-enzyme conjugate, LPO, potassium iodide, and glucose, was necessary for effective killing. No bactericidal activity was noted with antibody-enzyme conjugate alone.

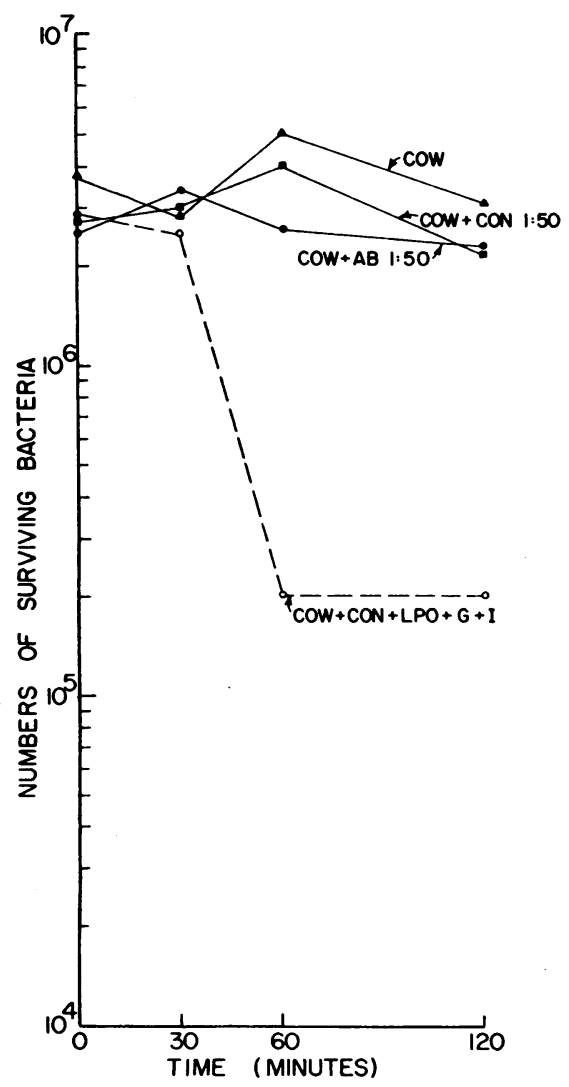

FIGURE 3 Bactericidal activity against the Cowan I strain of $S$. aureus was exhibited with anti-Cowan antibody-enzyme conjugate diluted 1:100, LPO, glucose, and potassium iodide (lower curve marked $\mathrm{COW}+\mathrm{CON}+\mathrm{LPO}+\mathrm{G}+\mathrm{I}$ ). Neither antibody (COW $+\mathrm{AB}$ 1:50) nor conjugate alone $(\mathrm{COW}+\mathrm{CON} 1: 50)$, even in a higher concentration, possessed intrinsic bactericidal activity; these controls along with colony counts of bacteria alone are shown in the three upper curves.
In substituting HPO for LPO in the $S$. aureus study, an HPO preparation obtained from Nutritional Biochemicals Corporation was employed. After several experiments it became apparent that this HPO preparation was not effective with conjugate dilutions of $1: 50$ or $1: 100$. That the antibody-enzyme conjugate had retained its activity was indicated by the effective killing it demonstrated when LPO was resubstituted with a conjugate dilution of $1: 100$. The reason for the discrepant behavior of the two different peroxidase preparations is not clear but may represent different effective levels of enzyme activity.

$\beta$-hemolytic Group $A$ streptococcus. Antibacterial antibody activity of isolated IgG preparations prepared against the M-33 strain MOR of $\beta$-hemolytic Group A streptococcus showed intense opsonic activity in the conventional Maalфe phagocytosis test $(11,12)$ using phagocytosing leukocytes. Such assays repeatedly showed rapid two-log drops in surviving bacteria establishing that the antibacterial rabbit IgG preparations were effective opsonins. When antibody-enzyme conjugates were used in a complete system without leukocytes, i.e. conjugate, LPO, glucose, and potassium iodide, rapid killing occurred. Dilutions of antibody-enzyme conjugate at $1: 10,1: 50$, and $1: 100$ showed rapid bactericidal activity and diminution of colony counts amounting to two-log drops within the first $30 \mathrm{~min}$ of the assay. The 1:100 dilution of antibody-enzyme conjugate contained $0.01 \mathrm{mg} / \mathrm{ml}$ of protein. Slight bactericidal activity was detectable in some experiments using conjugates at $0.001 \mathrm{mg} / \mathrm{ml}$ but no marked diminution in colony counts was recorded. Next to the results obtained with pneumococci, the bactericidal activity observed with antibody-enzyme conjugates directed against $\beta$-hemolytic streptococci was the most potent. Again a complete system employing all reactants was necessary.

Proteus mirabilis. Numerous experiments were performed in studying the test strain of $P$. mirabilis (GIL). Considerable difficulty in obtaining reproducible bacterial growth hampered precise colony enumeration. In some experiments colony swarming occurred. However, in several experiments where consistent growth was obtained, distinct bactericidal activity could be documented using the complete system of antibody-glucose oxidase conjugate diluted $1: 5$ and 1:50 along with the essential cofactors. The most distinct bactericidal effect was recorded at 1:5 dilutions of the conjugate (Fig. $4 a$ ) and, in parallel with this when tested in the modified in vitro phagocytosis test system using leukocytes $(11,12)$, the original unconjugated rabbit IgG antibody demonstrated only a one-log reduction in colony counts. This opsonic activity was not as potent as that which had been present in rabbit antibacterial antibodies against the QUI strain of pneumococcus, the M-33 strain of 


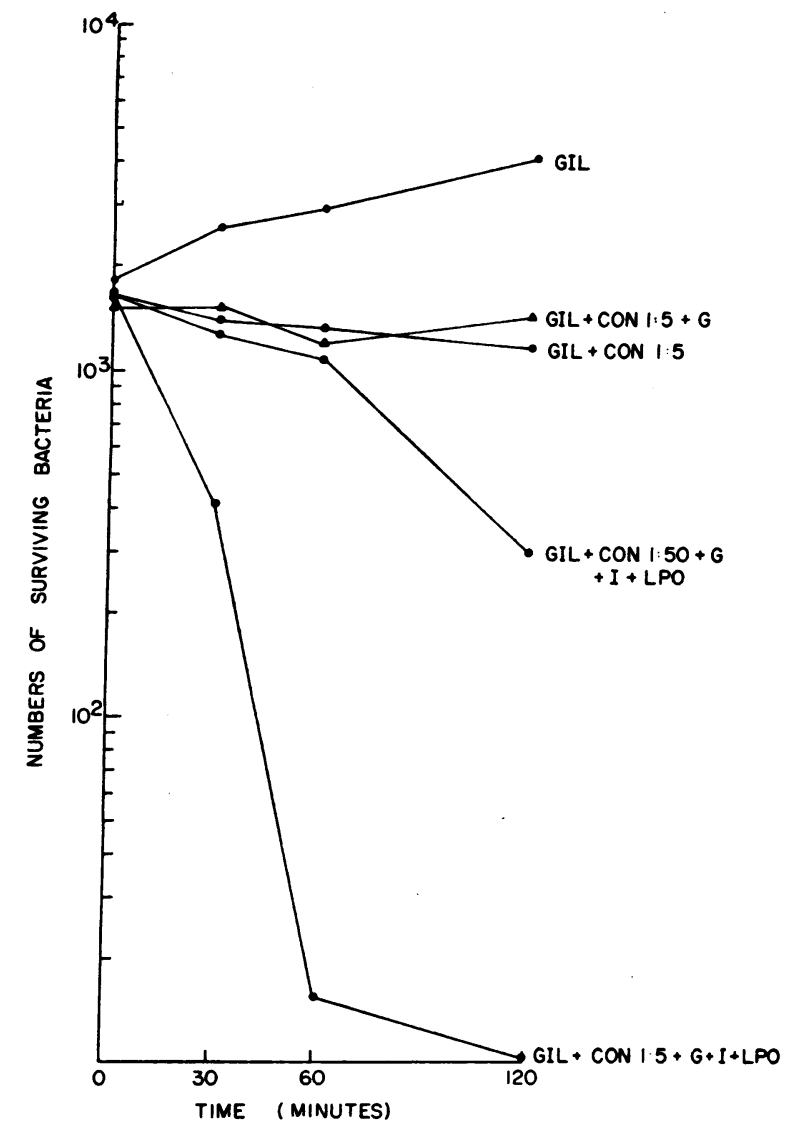

FIGURE $4 a$ Bactericidal activity recorded with antibodyenzyme conjugate against test strain of $P$. mirabilis GIL $1.46 \mathrm{mg} / \mathrm{ml}$ after dilution to $1: 5$ and $1: 50$. Upper curve (GIL) shows colony counts of bacteria alone. No killing was noted with bacteria plus conjugate $1: 5$ (GIL + CON $1: 5$ ) nor with bacteria plus conjugate plus glucose (GIL + CON 1:5+G). In addition LPO alone or in incomplete systems (curves not shown) produced no killing. Distinct bactericidal activity (lower curve GIL + CON $1: 5+\mathrm{G}+$ I + LPO) was noted with the complete system. Some diminution of this bactericidal activity was recorded using a higher dilution $(1: 50)$ of the conjugate. Concentrations of LPO used in this experiment were $10 \mu \mathrm{g} / \mathrm{ml}$, and for potassium iodide, $10 \mu \mathrm{g} / \mathrm{ml}$.

Group A streptococcus, or the Cowan I strain of $S$. aureus studied above.

Pseudomonas aeruginosa. Two $P$. aeruginosa organisms isolated from osteomyelitis patients (LAH and STA) (13) were studied in numerous experiments. Conjugates were tested for bactericidal activity against the corresponding organism as well as against the organism isolated from the other patients.

Rabbit IgG isolated from antisera against both STA and LAH strains exhibited moderate opsonic activity in the modified phagocytosis test system $(11,12)$ with only a one-log reduction in colony counts. This antibody- enzyme conjugate system did not demonstrate bactericidal activity. This was evident utilizing HPO or LPO and the conjugate in a $1: 5,1: 10,1: 50$, or $1: 100$ dilution and represented the only instance where bactericidal activity of antibody-enzyme complex was not demonstrable. Effective killing by antibody enzyme conjugates appeared to depend on strong antibacterial opsonic antibody as a participating member of the complex, but other factors possibly related to these two test strains were also involved.

Escherichia coli. Using a potent opsonic rabbit antibacterial IgG preparation which consistently produced a two-log drop in conventional phagocytosis, the bactericidal activity of antibody-enzyme conjugates was repeatedly demonstrated using conjugates at $1: 10$ dilution. These experiments constituted additional examples of effective bactericidal activity of antibody-enzyme conju-

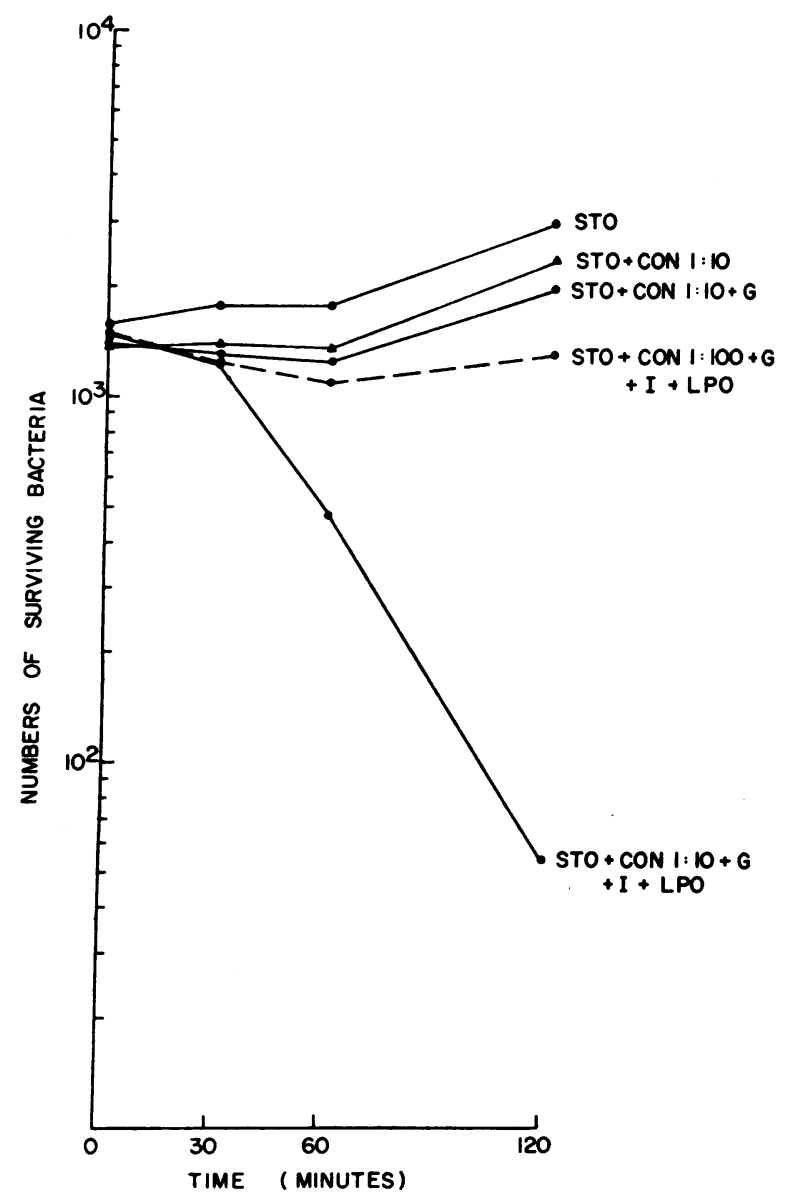

FIGURE $4 b$ Distinct bactericidal activity is shown in this experiment with test strain of $E$. coli (STO) plus a $1: 10$ dilution of antibody-enzyme conjugate and essential cofactors (STO + CON 1:10+G + I + LPO). No killing was recorded, however, using a 1:100 dilution of antibodyenzyme conjugate. 


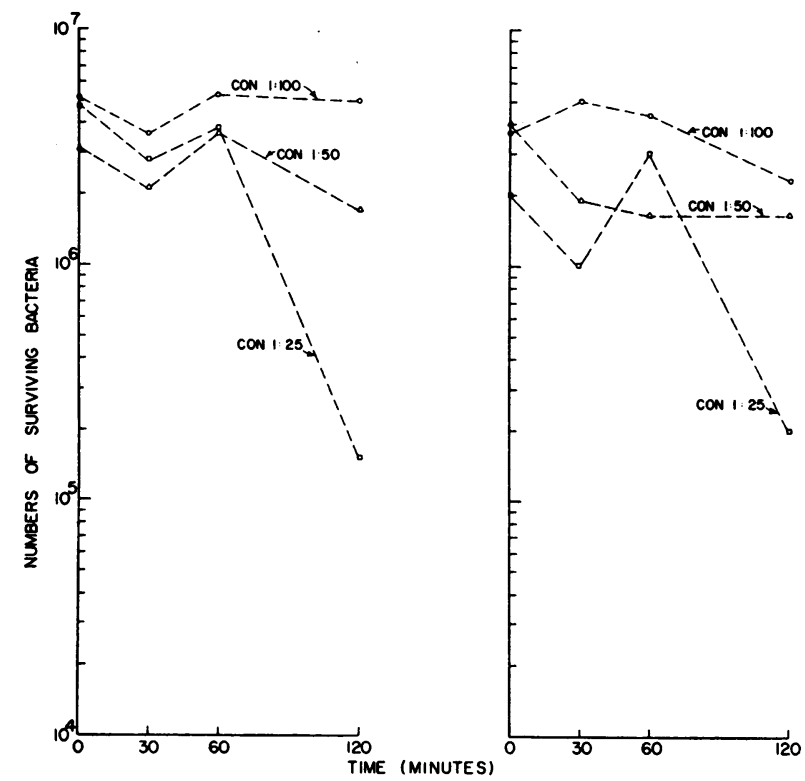

FIgURE 5 The immune IgG fraction of a patient (ELL) with subacute bacterial endocarditis ( $\mathrm{SBE}$ ), simultaneously infected with yellow and white strains of $S$. aureus, was conjugated to glucose oxidase. Curve on left shows the yellow strain of $S$. aureus incubated with HPO, potassium iodide, glucose, and a $1: 25,1: 50$, and $1: 100$ dilution of the IgG-enzyme conjugate. The curve on the right shows the white strain of $S$. aureus incubated with HPO, potassium iodide, glucose, and a $1: 25,1: 50$, and $1: 100$ dilution of the IgG-enzyme conjugate. No bactericidal activity was evident at a dilution of $1: 100$ with either organism. A two- to threefold reduction in colony counts was evident at a $1: 50$ dilution. At a $1: 25$ dilution a 10 -fold or a one-log reduction was noted indicating distinct bactericidal activity.

gates demonstrated with test strains of gram-negative bacteria (Fig. $4 b$ ) However, as in the case of the test strain of proteus a low dilution $(1: 10)$ of conjugate was necessary to insure killing.

It should be emphasized that several bacterial species possessing catalase (Cowan I strain of $S$. aureus and the STO strain of $E$. coli) were effectively killed in our test system so that bacterial catalase activity could not be used to predict resistance to the in vitro bactericidal activity of antibody-enzyme conjugates.

Studies with human antibody (SBE patient infected with two strains of $S$. aureus)

Previous work has demonstrated that the constant or intermittent bacteremia of SBE is often associated with the production of potent heat stable IgG opsonins (1922). For this reason an SBE patient (ELL) whose organisms and serum were available was selected for study. Two $S$. aureus strains, yellow and white, were simultaneously isolated. The patient's own immune IgG frac- tion was used in the preparation of an antibody-enzyme conjugate.

In a dilution of $1: 25$ the antibody-enzyme conjugate $\left(4.5 \times 10^{-3} \mathrm{mg}\right)$ combined with HPO, effectively killed both organisms. The bactericidal effect was not evident until $120 \mathrm{~min}$, no bactericidal activity being demonstrable at 0,30 , or $60 \mathrm{~min}$ (Fig. 5). These results are similar to those obtained with the Cowan I strain of $S$. aureus and totally different from the definite early downward slope of bactericidal activity seen with the test strain of pneumococcus (Fig. 2). A 1:50 dilution of the conjugated antibody demonstrated a downward trend but not so far as to register a one-log reduction in colony counts. The conjugate diluted 1:100 produced no noticeable effect (Fig. 5).

A second conjugate was prepared using IgG from a different patient with acute staphylococcal endocarditis. In parallel with the studies using rabbit opsonins, the bactericidal activity of this conjugate, though weakly effective, was not as strong as that recorded for the ELL conjugates above. In this latter instance the intrinsic opsonic activity of the unconjugated IgG from the patient with acute bacterial endocarditis was considerably weaker than that associated with SBE.

\section{Specificity of bactericidal effect}

The specificity of the bactericidal systems under study appeared to be mediated by the presence of antibody directed against the test organism. Conjugation of glucose oxidase to IgG, its incubation with bacteria to allow antibody fixation, and subsequent washing to discard nonspecific conjugated IgG made the presence of the hydrogen peroxide-generating system dependent upon an adequate opsonic or antibody-combining system.

In the experiments reported above, the most effective conjugate preparations were the antipneumococcus, antistreptococcal, and anti-E. coli conjugates which were rapidly bactericidal in high dilutions in the presence of iodide and LPO. Bactericidal activity was specific for the test organism against which the antibacterial antibody was directed, since no killing was observed when antibody-enzyme conjugates were tested with other noncross-reactive bacteria. Thus, antibody-enzyme conjugate prepared against $S$. aureus did not kill $P$. mirabilis or pneumococcal test strains.

\section{DISCUSSION}

The in vitro experiments documented here indicate that either rabbit or human antibacterial IgG antibody conjugated to the enzyme glucose oxidase via DEM is a potent combination of the homing biologic specificity of antibody and an enzymatically genera':ed peroxide-dependent bactericidal system. 
Repeated experiments demonstrated that strong antibacterial combining (opsonic) activity was required for effective antibody-enzyme conjugate bactericidal activity. Indeed the effectiveness of the bactericidal activity of the complete system appeared to correlate with original opsonic aactivity. The addition of peroxidase (LPO or HPO), and oxidable cofactor (iodide ions in our experiments) and glucose as substrate for glucose oxidase, was necessary.

The components of the peroxidase- $-\mathrm{H}_{2} \mathrm{O}_{2}-$ halide system successfully employed against bacteria in vitro in these studies appear to be present in the leukocyte (23). MPO, localized in the azurophil or primary granule (24-27), has been estimated to constitute greater than $5 \%$ of the dry weight of the human neutrophil (28) and its release into the phagocytic vacuole has been demonstrated with the electron microscope $(8,29)$. It is believed that the necessary $\mathrm{H}_{2} \mathrm{O}_{2}$ is generated by the neutrophil during the respiratory burst $(30-33)$ or supplied by certain bacterial species, such as the pneumococcus or streptococcus in the course of their metabolism $(34,35)$. Since serum iodine is predominantly hormonal, iodide released from the thyroid hormones thyroxine and triiodothyronine may be the active cofactor in vivo (23). Indeed, iodide can be replaced by these hormones in a cell-free system (3). Chloride may also act as an important halide cofactor in vivo. The lethal effect of the peroxidase $-\mathrm{H}_{2} \mathrm{O}_{2}-$ halide system may result partly from the direct halogenation of certain bacterial proteins (23). Lastly, the optimal $\mathrm{PH}$ for this system is acid $(3,6)$, as is the intravacuolar $\mathrm{pH}(36,37)$.

The requirement for several cofactors beside the antibacterial antibody-enzyme conjugate may temporarily hinder the clinical application of this general approach. However, recent studies with antibody-glucose oxidase conjugates attached to tumor cells indicate that selective iodination can be obtained in vitro and in vivo $(38,39)$.

One theoretical objection to the general approach of coupling enzyme to active antibody is that the extremely reactive coupling reagent DEM may couple enzyme to portions of antibody molecules close to or obscuring the combining site. Preliminary data have indicated that prior combination of antibody with its antigen before enzyme coupling will protect the antibody-combining site. Thereafter antigen-antibody complexes can be dissociated and enzyme-coupled antibody effectively utilized. In our hands specific testing of antibacterial antibody activity of antibody-enzyme conjugates has shown some loss, particularly of antibacterial antibody complementfixing or -precipitating activity after enzyme conjugation; however, clear evidence for preservation of combining reactivity of antibody-enzyme conjugates was obtained by immunofluorescence.
If conjugation of helper or effector molecules to antibody proves to be a useful biologic manipulation, it is conceivable that basic functions of antibody molecules may eventually be altered or partially tailored to fit particular situations or needs. This would, of course, depend on choosing coupling reagents with limited or focused specificity and also on a more precise knowledge of specific immunoglobulin primary sequence data at or near areas of biologic importance, such as the opsonic site or the area involved in complement fixation or cytotoxicity. Antibody-enzyme conjugates with clear in vitro and in vivo bactericidal activity may conceivably be of practical help in clinical situations where fulminant bacteremia or depression of leukocyte-host reactivity produces an unfavorable outcome.

\section{ACKNOWLEDGMENTS}

This work was supported in part by a grant from the Kroc Foundation and in part by grants 1-RO1-AM13824 and 5-TO1-AI00393 from the U. S. Public Health Service.

\section{REFERENCES}

1. Klebanoff, S. J., and R. G. Luebke. 1965. The antilactobacillus system of saliva: role of salivary peroxidase. Proc. Soc. Exp. Biol. Med. 118: 483.

2. Klebanoff, S. J., W. H. Clem, and R. G. Luebke. 1966. Peroxidase-thiocyanate-hydrogen peroxide antimicrobial system. Biochim. Biophys. Acta. 117: 63.

3. Klebanoff, S. J. 1967. Iodination of bacteria : bactericidal mechanism. J. Exp. Med. 126: 1063.

4. Klebanoff, S. J. 1968. Myeloperoxidase-halide-hydrogen peroxide antibacterial system. J. Bacteriol. 95: 2131.

5. Klebanoff, S. J. 1967. A peroxidase-mediated antimicrobial system in leukocytes. J. Clin. Invest. 46: 1078.

6. McRipley, R. J., and A. J. Sbarra. 1967. Role of the phagocyte in host-parasite interactions. XII. Hydrogen peroxide-myeloperoxidase bactericidal system in the phagocyte. J. Bacteriol. 94 : 1425.

7. Lehrer, R. I. 1969. Antifungal effects of peroxidase systems. J. Bacteriol. 99 : 361.

8. Klebanoff, S. J. 1970. Myeloperoxidase-mediated antimicrobial systems and their role in leukocyte function. In Biochemistry of the Phagocytic Process: Localization and the Role of Myeloperoxidase and the Mechanism of the Halogenation Reaction. J. Schultz, editor. North-Holland Publishing Co., Amsterdam. 89-110.

9. Belding, M. E., S. J. Klebanoff, and C. G. Ray. 1970. Peroxidase-mediated virucidal systems. Science (Wash., D. C.). $167: 195$.

10. Smith, D. C., and S. J. Klebanoff. 1970. A uterine fluid-mediated sperm-inhibitory system. Biol. Reprod. 3: 229.

11. Hirsch, J. G., and B. Strauss. 1964. Studies on heatlabile opsonin in rabbit serum. J. Immunol. 92: 145.

12. Maaløe, O. 1946. On the Relation between Alexin and Opsonin. Munksgaard, A/S, Copenhagen.

13. Williams, R. C., Jr., J. H. Dossett, and P. G. Quie. 1969. Comparative studies of immunoglobulin opsonins in osteomyelitis and other established infections. Immunology. $17: 249$.

14. Mandell, G. L., and E. W. Hook. 1969. Leukocyte bactericidal activity in chronic granulomatous disease: cor- 
relation of bacterial hydrogen peroxide production and susceptibility to intracellular killing. J. Bacterial. 100: 531.

15. Williams, R. C., Jr., and P. G. Quie. 1971. Opsonic activity of agammaglobulinemic human sera. J. Immunol. 106: 51 .

16. Dutton, A., M. Adams, and S. J. Singer. 1966. Bifunctional imidoesters as cross-linking agents. Biochem. Biophys. Res. Commun. 23 : 730.

17. Keston, A. S., and R. Brandt, 1965. The fluorometric analysis of ultramicro quantities of hydrogen peroxide. Anal. Biochem. 11: 1 .

18. Nickerson, D. S., J. G. White, G. Kronvall, R. C. Williams, Jr., and P. Quie. 1970. Indirect visualization of Staphylococcus aureus protein A. J. Exp. Med. 131: 1039.

19. Laxdal, T., R. P. Messner, R. C. Williams, Jr., and P. G. Quie. 1968. Opsonic agglutinating and complement-fixing antibodies in patients with subacute bacterial endocarditis. J. Lab. Clin. Med. 71: 638 .

20. Messner, R. P., T. Laxdal, P. G. Quie, and R. C. Williams, Jr. Serum opsonin, bacteria and polymorphonuclear leukocyte interactions in subacute bacterial endocarditis: anti- $\boldsymbol{\gamma}$-globulin factors and their interaction with specific opsonins. J. Clin. Invest. 47: 1109.

21. Quie, P. G., R. P. Messner, and R. C. Williams, Jr. 1968. Phagocytosis in subacute bacterial endocarditis: localization of the primary opsonic site to Fc fragment. J. Exp. Med. 128 : 553.

22. Messner, R. P., T. Laxdal, P. G. Quie, and R. C. Williams, Jr. 1968. Rheumatoid factors in subacute bacterial endocarditis-bacterium, duration of disease or genetic predisposition? Ann. Intern. Med. 68: 746.

23. Klebanoff, S. J. 1971. The myeloperoxidase-mediated antimicrobial system. In Phagocytic Mechanisms in Health and Disease. R. C. Williams, Jr., and H. Fudenberg, editors. Intercontinental Medical Book Corporation, New York. 3-21.

24. Bainton, D. F., and M. G. Farquhar. 1968. Differences in enzyme content of azurophil and specific granules of polymorphonuclear leukocytes. I. Histochemical staining of bone marrow smears. J. Cell Biol. 39: 286.

25. Bainton, D. F., and M. G. Farquhar. 1968. Differences in enzyme content of azurophil and specific granules of polymorphonuclear leukocytes. II. Cytochemistry and electron microscopy of bone marrow cells. J. Cell Biol. 39: 299.
26. Dunn, W. B., J. H. Hardin, and S. S. Spicer. 1968. Ultrastructural localization of myeloperoxidase in human neutrophil and rabbit heterophil and eosinophil leukocytes. Blood. 32 : 935.

27. Baggliolini, M., J. G. Hirsch, and C. de Duve. 1969. Resolution of granules from rabbit heterophil leukocytes into distinct populations by zonal sedimentation. J. Cell. Biol. 40 : 529 .

28. Schultz, J., and K. Kaminker. 1962. Myeloperoxidase of the leukocyte of normal human blood. I. Content and localization. Arch. Biochem. Biophys. 96: 465.

29. Baehner, R. L., M. J. Karnovsky, and M. L. Karnovsky. 1968. Degranulation of leukocytes in chronic granulomatous disease. J. Clin. Invest. 48: 187.

30. Iyer, G. Y. N., D. M. F. Islam, and J. H. Quastel. 1961. Biochemical aspects of phagocytosis. Nature. 192: 535.

31. Rechcig1, M., Jr., and W. H. Evans. 1963. Role of catalase and peroxidase in the metabolism of leukocytes. Nature. 199: 1001.

32. Paul, B., and A. J. Sbarra. 1968. The role of the phagocyte in host-parasite interactions. XIII. The direct quantitative estimation of $\mathrm{H}_{2} \mathrm{O}_{2}$ in phagocytizing cells. Biochim. Biophys. Acta. 156: 168.

33. Zatti, M., F. Rossi, and P. Patriarca. 1968. The $\mathrm{H}_{2} \mathrm{O}_{2-}$ production by polymorphonuclear leukocytes during phagocytosis. Experientia (Basel). 24: 669.

34. McLeod, J. W., and J. Gordon. 1922. Production of hydrogen peroxide by bacteria. Biochem. J. 16: 499.

35. McLeod, J. W., J. Gordon, and L. N. Pyrah. 1923 Further observations on peroxide formation by bacteria. J. Pathol. Bacteriol. 26: 127.

36. Rous, P. 1925. The relative reaction within living mammalian tissues. II. On the mobilization of acid materia within cells, and the reaction as influenced by the cell state. J. Exp. Med. 41 : 399.

37. Sprick, M. G. 1956. Phagocytosis of $M$. tuberculosis and $M$. smegmatis stained with indicative dyes. Am. Rev. Tuberc. Pulm. Dis. 74: 552.

38. Parker, C. W., R. Bower, R. D. Aach, and G. W. Philpott. 1972. The immunologic therapy of cancer. Proceedings of the Fifth International Congress on Pharmacology. Karger AG, Basel. In press.

39. Philpott, G. W., R. J. Bower, and C. W. Parker. 1972. Affinity cytotoxicity for tumor cells with antibody-enzyme conjugates. J. Clin. Invest. 51: 75 a. (Abstr.) 